\title{
Biochemical Traits and Physico-Chemical Attributes of Aromatic-Fine Rice in Relation to Yield Potential
}

\author{
M. Abdul Baset Mia ${ }^{1}$, Mira Rani Das ${ }^{1}$, Muhammad Kamruzzaman ${ }^{2}$, Nur Muhammad Talukder ${ }^{2}$ \\ ${ }^{1}$ Department of Crop Botany, Bangabandhu Sheikh Mujibur Rahman Agricultural University, Gazipur, Bangladesh; ${ }^{2}$ Department of \\ Agricultural Chemistry, Faculty of Agriculture, Bangladesh Agricultural University, Mymensingh, Bangladesh. \\ Email:miabaset@yahoo.com
}

Received September $24^{\text {th }}, 2012$; revised November $11^{\text {th }}$, 2012; accepted November $19^{\text {th }}, 2012$

\begin{abstract}
Aromatic rice has great potential to attract rice consumer for its taste and deliciousness, and high price to boost up the economic condition of the rice grower in the developing countries. A field experiment was conducted to evaluate the morpho-physiological and biochemical attributes in relation to yield potentials of fine aromatic rice varieties in Bangladesh. Two aromatic fine rice cultivars, Ukunmadhu and Kataribough (local land races), one hybridized variety BRRIdhan32 and one mutant variety Binasail were used in the experiment. The results revealed that rice varieties BRRIdhan32 and Binasail showed the greater number of branches of panicle, grain size, grain yield and harvest index as compared to aromatic varieties. On the other hand, aromatic rice showed taller plant stature, more tiller, plant biomass and larger panicle but lower number of primary and secondary branches, grain size, yield and harvest index. The biochemical attributes namely chlorophyll and soluble protein content were higher at vegetative stage as compared to panicle initiation and flowering stages. The aromatic rice Kataribhough and Ukonmondhu contained higher amount of total free amino acid as compared to that of Binasail and BRRIdhan32. Other biochemical parameters namely nitrate reductase activity (NRA), total sugar and free amino acid contents were higher at flowering stage compared to those contained at tillering and panicle initiation stages. Physico-chemical properties of grain viz. length, breadth, L/B ratio, nitrogen (\%) and protein (\%) were significantly higher in fine rice as compared to aromatic rice. From the results it may be concluded that the high yielding varieties were more efficient in transfer of photosynthate to the grain i.e. economic yield and that is why BRRIdhan32 recorded the highest yield. Poor yield in Ukonmodhu and Kataribhough was due to low harvest index indicating minimum translocation of assimilates to the grains.
\end{abstract}

Keywords: Biochemical Properties; Aromatic Rice; Yield; Grain Quality

\section{Introduction}

The demand of aromatic rice is increasing gradually throughout the world for its taste and pleasant flavor. It constitutes a small but special group which is considered best in quality. It is regarded as best in quality and fetch much higher price than normal non-aromatic rice and can add just the right amount of flavor and depth to any simple rice dish [1]. In Bangladesh, it is a high value calorie producing carbohydrate which contributes significantly in the agricultural trade market for having small grain, amusing aroma, with soft texture upon cooking [2]. However, the yield of aromatic rice is comparatively lower than that of coarse and medium [3] and most of high quality aromatic rice are low yielding [4]. They are mainly traditional and local land races which have taller plant stature and inefficient fertilizer responses. However, due to favorite flavor and other better grain qualities it is important resources for breeding and improving the aromatic rice cultivars for diverse demand of consumers in the world [1].

The reasons for low yield are mainly associated with lack of high yielding varieties (HYV) which plays vital role in greater production.

Physiological characters of the plant are inherent characters determining the crop yield which plays an important role in variety selection [5]. Development of rice cultivars with a high yielding ability is one of the most fundamental approaches for dealing with the expected increases in the world demand. Keeping the quality of aroma and other grain quality in aromatic fine rice is a big challenge as yield is inversely related to protein and aroma content [6].

It is well known that traditional cultivars of aromatic rice are not able to utilize the nitrogen fertilizer efficiently as their nitrate reductase activity (NRA) is very 
higher thereby luxuriant growth happened consequently the plant become lodge, and yield reductions are caused due to lodging behavior. In such varieties, certain architectural and physiological defects cause significant problems with assimilate translocation. Moreover, the biochemical attributes of those varieties has not yet been determined comprehensively. Rice plants depend solely upon soil and applied sources of nitrogen for maximum yield. In the developing countries, urea is mainly used as a source of nitrogen fertilizer for rice plants, where urea after application converts to ammonia by hydrolysis in the soil. All the ammonium from this source is not utilized by the plants, and only about $40 \%$ of this applied nitrogen is utilized by the rice plant. Rice plants can also utilize nitrate as an alternative source of nitrogen. Whatever the form of nitrogen is applied in the soil, it is synthesized into amino acids and amides for incorporation into the carbon skeletons of different organic molecules. This conversion of nitrogen to amide and amino acids is regulated by the nitrogen assimilating enzymes [7]. For upland crops, nitrate reductase (NR) is the main nitrogen assimilating enzymes which is substrate inducible.

At the present situation it is necessary to increase per hectare yield of aromatic fine rice, and breeders are trying to develop for achieving higher yield and improve grain quality. However, the grain quality and its relation to yield and physiological attributes have not been determined. Therefore, the experiment was conducted with the objectives of investigating the physicochemical properties of three categories i.e. fine aromatic, medium fine non aromatic and coarse grain rice varieties for establishing relationship with yield and suggest for further improvement.

\section{Materials and Methods}

The experiment was conducted at the experimental farm of the Bangladesh Institute of Nuclear Agriculture (BINA), Mymensingh, Bangladesh. Two traditional varieties of aromatic rice namely, Ukunmodhu and Kataribhough, one mutant rice variety (developed from Nizersail through $\gamma$-ray irradiation) having medium grain size Binasail and a hybridized rice variety (obtained from a cross between BR4 $\times$ BR2264 by Bangladesh Rice Research Institute, Bangladesh) were used as a test crop for this experiment [8]. The physico-chemical properties of the soil was: $\mathrm{pH}-6.10$, organic matter $-0.96 \%$, total $\mathrm{N}-0.07 \%, \mathrm{P}-12 \mathrm{ppm}, \mathrm{K}-0.10 \mathrm{me} \%$, S-10 ppm, Zn $-1.03 \mathrm{ppm}$ and $\mathrm{B}-0.79 \mathrm{ppm}$.

The experiment was laid out in a randomized complete block design (RCBD) with five replications. The whole amount of muriate of potash (MOP) $\left(20 \mathrm{~kg} \cdot \mathrm{ha}^{-1}\right)$, triple super phosphate (TSP) (18 kg.ha-1), gypsum (S 12 $\mathrm{kg} \cdot \mathrm{ha}^{-1}$ ) was applied at the final land preparation. Nitrogen at the rate of $70 \mathrm{~kg} \cdot \mathrm{ha}^{-1}$ was applied in the form of urea in three equal splits at 15 days after transplanting, active tillering and panicle initiation stages. Thirty-day old single seedling was transplanted in a hill with plant to plant distance $15 \mathrm{~cm}$ and row to row distance $20 \mathrm{~cm}$. Weeding and irrigation were done as and when necessary. Harvesting was done when $80 \%$ to $90 \%$ of the grain became golden in color. Ten hills (excluding border hills) were randomly selected outside a one $\mathrm{m}^{2}$ area kept for yield data from each unit plot. Grain yield was determined by harvesting the one $\mathrm{m}^{2}$ area which was prefixed at the center of each plot. The harvested crops were threshed and cleaned, and the grain weight (14\% moisture) was recorded after drying in the sun. Biochemical parameters namely nitrate reductase activity (NRA), soluble protein, total free amino acids, chlorophyll content were computed followed by standard methods [9-11] at different growth stages. Harvest index, the ratio between economic yield and biological yield [12] was calculated by using the following formula:

$$
\text { Harvest Index }(\%)=\frac{\text { Economic yield }}{\text { Biological yield }} \times 100
$$

\subsection{Physico-Chemical Properties of Grain}

Length and breadth of kernels were estimated with the help of slide calipers and length:breadth ratio was calculated accordingly. Determination of total nitrogen of grain was done by micro-Kjeldahl method [13].

\subsection{Protein Content}

The grain protein content was determined through digesting the grains by micro-Kjeldahl method. The digested samples were analysed for $\mathrm{N}$ estimation which was determined by Autoanalyzer (Technicon II, Technicon Ltd.). The protein content of the grain was determined by multiplying the $\mathrm{N}$ content of grain by 5.95 and the result was expressed in percentage.

\subsection{Statistical Analysis}

Collected data on different parameters were analyzed statistically. Analyses of variance were done following RCBD with the help of computer MSTAT-C package programme developed by Russel [14]. The means were adjudged by Duncan's Multiple Range Test [15].

\section{Results}

\subsection{Biochemical Characteristics}

\subsubsection{Chlorophyll a}

Chlorophyll a decreased gradually with the advancement of growth stages (Figure 1). The variety Ukonmodhu showed the highest chlorophyll-content at all the three stages. Among the varieties, there was no significant 


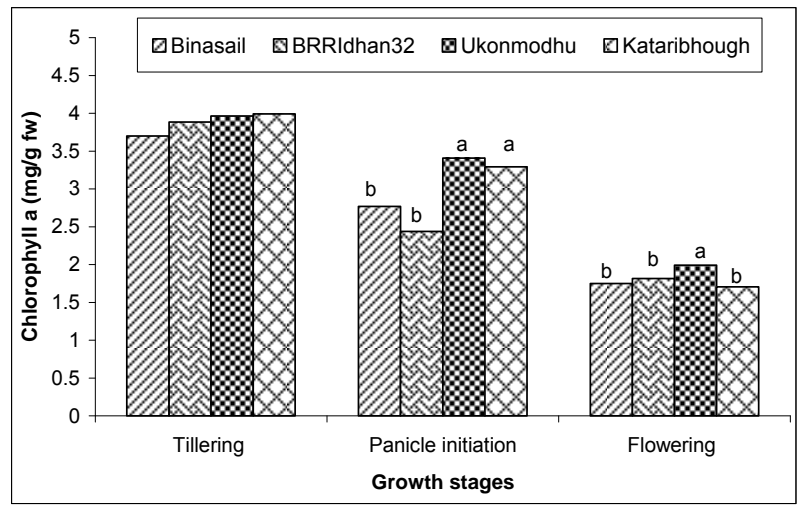

Figure 1. Chlorophyll-a of leaf at different growth stages of four aromatic and fine rice varieties.

variation in chlorophyll a content at tillering stage (Figure 1). All the varieties showed similar amount of chlorophyll a. But at panicle initiation and flowering stages, chlorophyll content differed significantly among the varieties. It was apparent in panicle initiation stage that the Ukonmodhu and Kataribhough showed similar amount of chlorophyll-a. At flowering stage, the highest amount of chlorophyll-a was recorded in Ukonmodhu.

\subsubsection{Chlorophyll b}

There were significant differences in chlorophyll b content at all the growth stages (Figure 2) which decreased gradually from tillering to flowering stages. The chlorophyll-b content of BRRIdhan32 was higher both at tillering and panicle initiation stages however, Binasail showed higher values at flowering stage. At tillering stage, the highest amount of chlorophyll-b was recorded in BRRIdhan32. Binasail showed the lowest amount of chlorophyll-b at panicle initiation stage, the highest amount of chlorophyll-b was found in BRRIdhan32 and the lowest quantity was found in Binasail. At flowering stage, Binasail recorded the highest and Kataribhough showed the lowest amount of chlorophyll-b.

\subsubsection{Total Chlorophyll}

Total chlorophyll content decreased gradually from tillering to flowering stages (Figure 3). BRRIdhan32 and Ukonmodhu recorded the higher amount while Binasail showed the lowest amount of total chlorophyll at all the three stages. At tillering stage, among three varieties Kataribhough, Ukonmodhu and BRRIdhan32 showed similar amount of total chlorophyll. Only Binasail showed the lowest amount of total chlorophyll at tillering stage. At panicle initiation stage, BRRIdhan32, Ukonmodhu and Kataribhough showed similar amount of total chlorophyll but Binasail showed the lowest amount of total chlorophyll. At flowering stage, Ukonmodhu showed the highest amount of total chlorophyll.

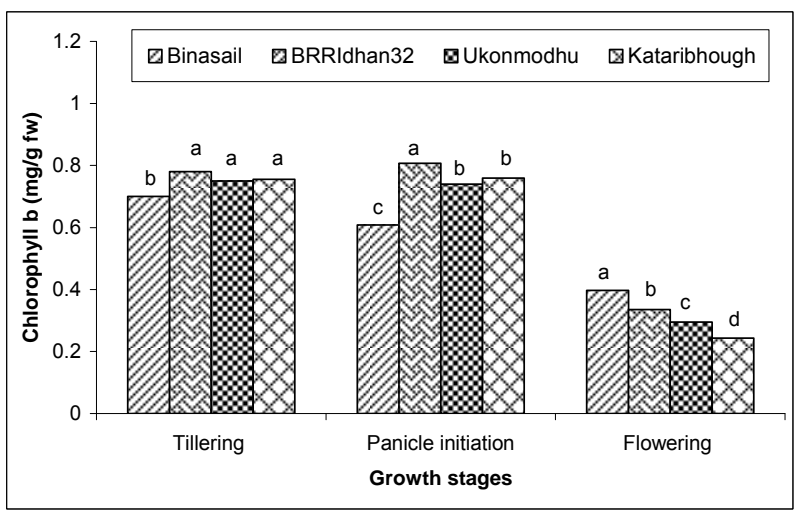

Figure 2. Chlorophyll-b of leaf at different growth stages of four aromatic and fine rice varieties.

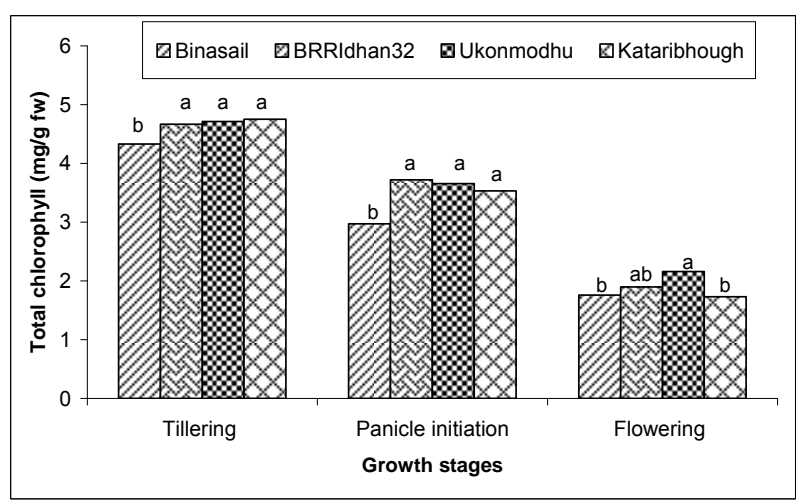

Figure 3. Total chlorophyll of leaf at different growth stages of four aromatic and fine rice varieties.

\subsubsection{Chlorophyll a/b Ratio}

Ukonmodhu and Kataribhough recorded similar amount of chlorophyll a/b ratio at all three stages (Figure 4). At tillering stage, there was no significant difference in chlorophyll a/b ratio among the varieties. All the varieties showed similar amount of chlorophyll a/b ratio and they were statistically identical. But there was significant difference at both panicle initiation and flowering stages. At panicle initiation stage, Binasail, Ukonmodhu and Kataribhough showed similar amount, and they were statistically identical, but BRRIdhan32 showed the lowest amount of chlorophyll a/b ratio. At flowering stage, Kataribhough and Ukonmodhu showed similar amount of chlorophyll a/b and both were identical. Binasail recorded the lowest amount of chlorophyll $\mathrm{a} / \mathrm{b}$ ratio and BRRIdhan32 and Binasail were not identical as Ukonmodhu and Kataribhough.

At tillering stage, the chlorophyll-a and a/b ratio did not show significant differences. These results were partially supported by Murchie et al. [16] who showed that leaf area; leaf area index and chlorophyll content were not significantly different between cultivars. Chlorophylla, chlorophyll-b, total chlorophyll and chlorophyll a/b 




Figure 4. Chlorophyll-a/b of leaf at different growth stages of four aromatic and fine rice varieties.

ratio all of these were higher at tillering stage as compared to that of panicle initiation and flowering stages. It means that the light harvest efficiency decreased at panicle initiation and flowering stages as compared to tillering stage.

\subsubsection{Nitrate Reductase Activity}

The maximum NRA was attained at flowering stage as compared to panicle initiation and tillering stages and NRA is gradually increase at tillering to flowering stages (Figure 5). At tillering stage, BRRIdhan32 showed the highest amount of NRA and Binasail recorded the lowest amount of NRA. At panicle initiation stage, BRRIdhan32 showed the highest amount of NRA. Binasail and Ukonmodhu were statistically identical and Kataribhough showed the lowest amount of NRA. At flowering stage, Kataribhough showed the highest amount of NRA and BRRIdhan32 showed the lowest amount of NRA.

Nitrate reductase catalyzes the reduction of nitrate to nitrite, which is considered rate-limiting in nitrate assimilation in plants and nitrate assimilating organisms. NRA in plants is regulated by nitrate, light, growth hormones, reduced nitrogen metabolites, and phosphorylation [17]. The results showed that NRA is gradually increased at tillering to flowering stages. The highest NRA was recorded at flowering stage. This pattern may be attributed to nitrate availability in the soil which would influence the NRA. This is expected because NR is a substrate-inducible enzyme.

\subsubsection{Soluble Protein}

The results indicated that soluble protein decreased at flowering stage as compared to that of maximum tillering stage. There was no significant difference in soluble protein content among varieties at both tillering and flowering stages (Figure 6).

The quantity of soluble protein is one of the important factors for synthesis of other plant material. The synthesis of soluble protein by plants depends upon their capac-

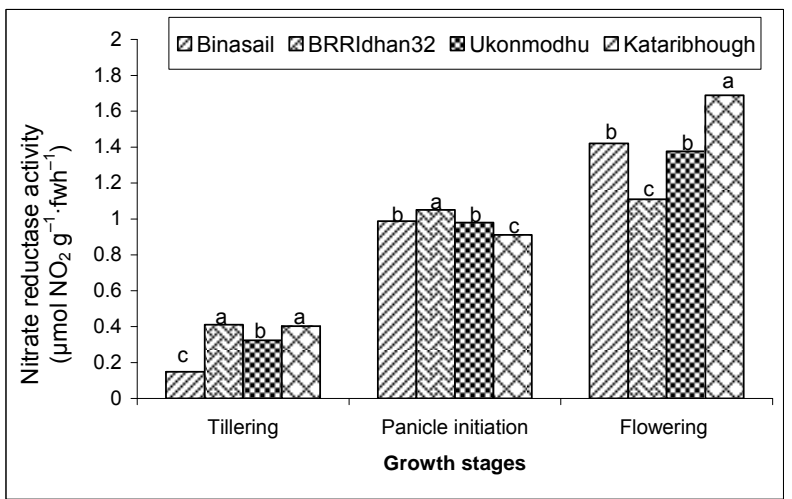

Figure 5. Nitrate reductase activity of leaf at different growth stages of four aromatic and fine rice varieties.

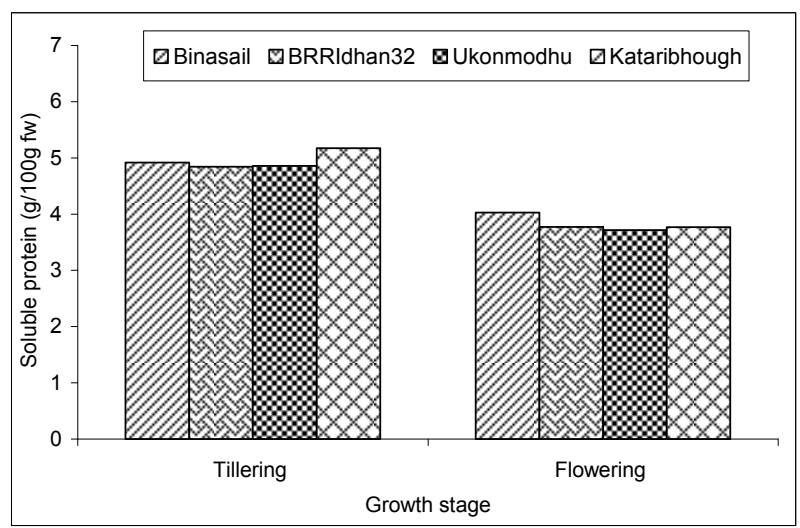

Figure 6. Soluble protein of leaf at different growth stages of four aromatic and fine rice varieties.

ity to utilize $\mathrm{N}$ and production of reduced- $\mathrm{N}$ needed for protein synthesis. In the present study, soluble protein was not changed, which might be due to the uniform availability of $\mathrm{N}$-fertilizer.

\subsubsection{Total Sugar}

Total sugar content increased at flowering stage as compared to tillering stage, including active synthesis of carbohydrates at flowering stage of rice. The result also showed that the total sugar content was higher in fine rice as compared to aromatic rice. There was significant difference in total sugar content among the varieties both at tillering and flowering stages (Figure 7). BRRIdhan32 recorded the higher values of sugar content and Ukonmodhu showed the lower value. At flowering stage, $\mathrm{Bi}$ nasail recorded higher value and Ukonmodhu obtained the lower amount of total sugar content.

\subsubsection{Total Free Amino Acid}

There was significant difference of total free amino acid content at tillering and flowering stages of the four rice varieties. The amino acid content was increased at flowering stage as compared to that of tillering stage of rice 




Figure 7. Total sugar content of leaf at different growth stages of four aromatic and fine rice varieties.

(Figure 8). At tillering stage, Kataribhough showed the higher value and BRRIdhan32 resulted in the lower amount of total free amino acid content. At flowering stage, Kataribhough also recorded higher value which was identical to Ukonmodhu.

The increase of amino acid at later stage indicated more synthesis of free amino acid at flowering stage which has significance in grain filling with assimilates containing soluble protein and carbohydrate. The result also showed that the aromatic rice Kataribhough and Ukonmondhu contained much amount of total free amino acid as compared to that of Binasail and BRRIdhan32. This result is supported by the report of Adak and Gupta [18]. They found the highest amino acid content in Latisail. Ali et al. [19] also found the highest free amino acid content (12.136\%) in aman variety.

\subsection{Yield and Yield Components}

\subsubsection{Plant Height}

Ukonmodhu recorded the highest plant height whereas the shortest plant height was recorded in BRRIdhan32 (Table 1). The result also showed that there was significant difference in plant height of Ukonmodhu, Kataribhoug and BRRIdhan32 but there was no significant difference between. Ukonmodhu, Binasail and Kataribhough.

\subsubsection{Number of Tillers}

There was significant difference in number of tillers hill ${ }^{-1}$ among the cultivars (Table 1). It was apparent that the tiller producing capacity of Kataribhough, Ukonmodhu and Binasail were not similar but the maximum number of total tillers hill ${ }^{-1}$ was recorded in Kataribhough and the minimum number of total tillers hill ${ }^{-1}$ was in Binasail.

\subsubsection{Panicle Length}

Binasail recorded the longest and BRRIdhan32 showed the shortest panicle length (Table 1). The result also showed that there was no significant difference in panicle

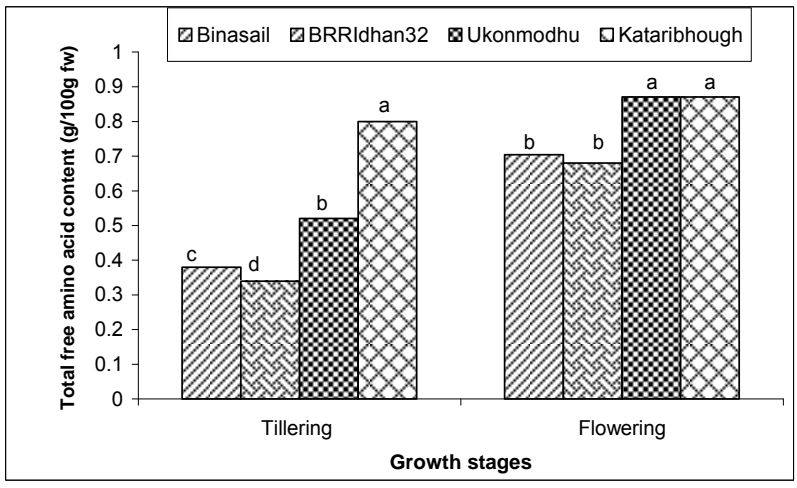

Figure 8. Total free amino acid content of leaf at different growth stages of four aromatic and fine rice varieties.

length of Binasail, Ukonmodhu and Kataribhough but varied in BRRIdhan32.

\subsubsection{Number of Primary Branche}

Ukonmodhu showed the greatest number whereas Binasail recorded the lowest number of primary branches. The remaining varieties showed the intermediate status (Table 1).

\subsubsection{Number of Secondary Branche}

Binasail produced the highest and Kataribhough recorded the lowest number of secondary branches (Table 1) Rachis branching system i.e. primary and secondary branching is one of the important factors for determining yield. Panicles having relatively large number of primary rachis-branches than secondary branches would be high yielding. Yamagishi et al. [20] ported that rachis-branching system in a panicle is an important factor determining the yield. They found high yielding variety to have a relatively large number of primary rachis-branches as compared with the secondary rachis-branches.

\subsubsection{0-Grain Weight}

There were spectacular and significant differences of 1000-grain weight among the cultivars (Table 1). The highest 1000-grain weight was recorded in BRRIdhan32. The other two cultivars Binasail and Kataribhough showed similar 1000-grain weight, respectively. The Ukonmodhu showed the lowest 1000 -grain weight.

\subsection{Grain Yield}

The results showed that BRRIdhan32 produced the maximum grain yield (Table 1). On the other hand, varieties Ukonmodhu and Kataribhough produced similar grain yield. The highest grain yield in BRRIdhan32 might be due to highest total dry matter production.

\subsection{Harvest Index}

The highest harvest index was recorded in BRRIdhan32 
Table 1. Plant height, yield and yield components of four different varieties of aromatic and fine rice.

\begin{tabular}{|c|c|c|c|c|c|c|c|c|}
\hline Variety & $\begin{array}{l}\text { Plant height } \\
\text { (cm) }\end{array}$ & $\begin{array}{l}\text { Number of total } \\
\text { tillers hill }\end{array}$ & $\begin{array}{l}\text { Panicle length } \\
\text { (cm) }\end{array}$ & $\begin{array}{c}\text { Number of } \\
\text { primary branches }\end{array}$ & $\begin{array}{l}\text { Number of secondary } \\
\text { branches }\end{array}$ & $\begin{array}{l}\text { 1000-grain } \\
\text { weight (g) }\end{array}$ & $\begin{array}{l}\text { Grain yield } \\
\left(\mathrm{t} \cdot \mathrm{ha}^{-1}\right)\end{array}$ & $\begin{array}{c}\text { Harvest } \\
\text { Index }\end{array}$ \\
\hline Binasail & $158 \mathrm{ab}$ & $7.00 \mathrm{c}$ & $26.94 \mathrm{a}$ & $26.48 \mathrm{~b}$ & 99.16 a & $17.14 \mathrm{~b}$ & $3.89 \mathrm{~b}$ & $40.99 \mathrm{~b}$ \\
\hline BRRIdhan32 & $127 \mathrm{c}$ & $7.50 \mathrm{bc}$ & $24.90 \mathrm{~b}$ & $28.60 \mathrm{ab}$ & $84.79 \mathrm{c}$ & $21.54 \mathrm{a}$ & $5.21 \mathrm{a}$ & $43.48 \mathrm{a}$ \\
\hline Ukonmodhu & $168 \mathrm{a}$ & $7.90 \mathrm{~b}$ & $26.42 \mathrm{a}$ & $31.17 \mathrm{a}$ & $95.00 \mathrm{~b}$ & $11.52 \mathrm{c}$ & $2.77 \mathrm{c}$ & $33.41 \mathrm{~d}$ \\
\hline Kataribhough & $150 \mathrm{~b}$ & $9.46 \mathrm{a}$ & $26.25 \mathrm{a}$ & $27.92 \mathrm{ab}$ & $51.03 \mathrm{~d}$ & $16.88 \mathrm{~b}$ & $2.90 \mathrm{c}$ & 35.67 c \\
\hline
\end{tabular}

In a column figures having common letter(s) do not differ significantly as per DMRT.

and the lowest in Ukonmodhu (Table 1). The results indicated that the harvest index differed among the varieties which were in agreement with the findings of $\mathrm{Fu}$ et al. [21]. Cui-Jing et al. [22] also observed higher grain yield and 1000-grain weight with the increased harvest index (HI).

\subsection{Grain Quality}

\subsubsection{Kernel Length}

The length of kernel of different varieties was significantly different (Table 2) where the highest kernel length was recorded in Kataribhough and the lowest length was recorded in Ukonmodhu. Fujita et al. [23] reported that the length of rice grain was positively correlated between grain weight and grain length.

\subsubsection{Kernel Breadth}

The breadth of kernel of different varieties was significantly different (Table 2). However, there was no significant variation among the kernel breadth of the three varieties Binasail, Ukonmodhu and Kataribhough. The highest breadth was observed in BRRIdhan32.

The present findings supported the reports of Fujita et al. [23] who obtained significantly positive correlation between grain weight and breadth.

\subsubsection{Length-Breath Ratio}

$\mathrm{L} / \mathrm{B}$ ratio indicates the shape and size of rice kernel which are important quality characters of rice, the highest $\mathrm{L} / \mathrm{B}$ ratio was recorded in Kataribhough and the lowest in Ukonmodhu (Table 2).

\subsubsection{Nitrogen Content}

The highest nitrogen content was observed in Binasail (1.77\%). Other varieties Ukonmodhu (1.54\%); BRRIdhan32 (1.53\%) and Kataribhough (1.53\%) were statistically identical in respect to nitrogen content (Table 2). Kadu et al. [24] reported that total N content and its uptake both in the rice grain and straw increased significantly with increasing rate of $\mathrm{N}$-application.

\subsubsection{Protein Content}

The highest protein content was recorded in Binasail
(10.53\%) (Table 2). Other cultivars showed similar protein content and they were statistically identical.

\section{Discussion}

Results showed that varieties had significant difference on plant height, total tillers hill ${ }^{-1}$ and panicle length, number of primary and secondary branches, 1000 grain weight, grain yield, harvest index, leaf area index, total dry matter, chlorophyll, total sugar, NRA, and amino acid content. Only soluble protein did not show any difference among the varieties. They also showed significant difference on physioco-chemical characters of grain viz; length, breadth, L/B ratio, nitrogen and protein contents.

Mutant rice variety Binasail produced the tallest plant stature and largest panicle length; the higher number of secondary branches, leaf area index, total dry matter, nitrogen content and protein content. The lower number of total tillers hill $^{-1}$, chlorophyll content, NR activity, total free amino acid content and L/B ratio of these varieties were studied. The higher $\mathrm{N}$ contents are the conesquent of greater nitrogen assimilation capacity as indicated by higher NR activity. A large amount of $\mathrm{N}$ is allocated to the leaf for example $60 \%-70 \% \mathrm{~N}$ is come from the leaf and $20 \%$ - 30\% from the leaf sheath [25]. Large part of $\mathrm{N}$ is invested in photosynthetic apparatuses namely chloroplast and chlorophyll. In mature leaves about $80 \%$ of $\mathrm{N}$ is allocated to chloroplast [26]. The amount of Rubisco increased with opening of leaf and become maximum when leaf expansion is completed. Rubisco synthesis is more active during leaf expanded [27]. Recently, more emphasis has given to genetic and biochemical aspect of biosynthesis of chlorophyll content namely chlorophyll a, chlorophyll b and chlorophyll a/b ratio and light harvesting chl a/b protein. There is positive correlation between total nitrogen content and protein nitrogen content in rice plant at heading and maturity stage [28].

BRRIdhan32 showed the higher value in number of primary branches, 1000-grain weight, grain yield, harvest index, NRA, chlorophyll b, total chlorophyll, total sugar, kernel length and breadth. It also showed the lower value of plant height, number of total tillers/hill, 
Table 2. Physico-chemical attributes of different aromatic and fine rice varieties.

\begin{tabular}{cccccc}
\hline Variety & Kernel length $(\mathrm{mm})$ & Kernel breadth $(\mathrm{mm})$ & Length-breadth ratio & Nitrogen content (\%) & Protein content (\%) \\
\hline Binasail & $7.31 \mathrm{~b}$ & $2.17 \mathrm{~b}$ & $3.35 \mathrm{c}$ & $1.77 \mathrm{a}$ & $10.53 \mathrm{a}$ \\
BRRIdhan32 & $8.20 \mathrm{a}$ & $2.26 \mathrm{a}$ & $3.63 \mathrm{~b}$ & $1.53 \mathrm{~b}$ & $9.13 \mathrm{~b}$ \\
Ukonmodhu & $6.18 \mathrm{c}$ & $2.15 \mathrm{~b}$ & $2.88 \mathrm{~d}$ & $1.54 \mathrm{~b}$ & $9.14 \mathrm{~b}$ \\
Kataribhough & $8.25 \mathrm{a}$ & $2.10 \mathrm{~b}$ & $3.93 \mathrm{a}$ & $1.53 \mathrm{~b}$ & $9.10 \mathrm{~b}$ \\
\hline
\end{tabular}

In a column figures having common letter (s) do not differ significantly as per DMRT.

panicle length, number of secondary branches, chlorophyll-a, a/b ratio, total free amino acid and protein content. Rice materials with good adaption of $\mathrm{N}$ were due to higher nitrate reductase activity (NRA) at low nitrogen conditions, more chlorophyll content and, the soluble protein in high nitrogen conditions and the Rubisco mobilized in N-free conditions as well [29].

On the other hand, aromatic rice Ukonmodhu showed the highest plant height and larger panicle length. It also showed the highest number of primary branches, total dry matter, chlorophyll a, total chlorophyll, chlorophyll $\mathrm{a} / \mathrm{b}$ ratio and total free amino acid content. The other parameters like 1000 grain weight, grain yield, harvest index, leaf are index, NRA, total sugar, and about all the grain quality characters recorded lowered by this variety.

Another aromatic variety Kataribhough showed maximum number of total tillers/hill and larger panicle length. It also showed higher value of TDM, NRA, Chlorophyll a, total chlorophyll, a/b ratio, total free amino acid content, kernel length and L/B ratio. The number of seconddary branches, grain yield, harvest index, kernel breadth, nitrogen and protein content were also recorded lowered by this variety.

The overall results of the field experiment demonstrated that BRRIdhan32 had the best agronomic performance for grain yield and harvest index. Binasail showed the highest protein contents amongst varieties. Another two aromatic varieties showed the lowest performance in grain yield and protein content also. On the other hand, it may be concluded from the present study that the high yielding varieties were more efficient in transfer of photosynthate to the sink reflecting the higher harvest index. The highest grain yield of BRRIdhan32 was due to the highest harvest index. Poor yield in Ukonmodhu and Kataribhough was due to low harvest index.

\section{REFERENCES}

[1] N. L Hien, W. S Ahmad, Y. Oikawa and Y. Hirata, "Genetic Diversity of Morphological Responses and the Relationships among Asia Aromatic Rice (Oryza sativa L.) Cultivar,” Tropics, Vol. 16, No. 4, 2007, pp. 343-355. doi:10.3759/tropics.16.343

[2] R. K. Dutta, B. P. Lahiri and M. A. B Mia, "Characteris- tics of Some Aromatic Fine Rice Cultivars in Relation to Their Physico-Chemical Quality of Grains,” Indian Journal of Plant Physiology, Vol. 3, No. 1, 1998, pp. 61-64. doi:10.1626/jcs.65.672

[3] S. Chandra and P. Jitendra, "Effect of Nitrogen Level of the Growth and Yield of Different Rice Cultivars," Indian Journal of Agronomy, Vol. 41, No. 3, 1996, pp. 96-115.

[4] A. Shakeel, A. Hussain, H. Ali and A. Ahmad, "Transplanted Fine Rice (Oryza sativa L.) Productivity as Affected by Plant Density and Irrigation Regimes,” International Journal of Agriculture and Biology, Vol. 7, No. 3, 2005, pp. 445-447.

[5] M. N. H. Miah, Yoshida, Y. Yamamoto and Y. Nitta, "Characteristics of Dry Matter Production and Partitioning of Dry Matter to Panicles in High Yielding Semi Dwarf Indica and Japonica Indica Hybrid Rice Varieties," Japanese Journal of Crop Science, Vol. 65, No. 4, 1996, pp. 672-685.

[6] G. L. Terman, R. E. Ramig, A. F. Dreier and R. A. Olson, "Yield-Protein Relationships in Wheat Grain, as Affected by Nitrogen and Water," Agronomy Journal, Vol. 61, No. 5, 1969, pp. 755-759. doi:10.2134/agronj1969.00021962006100050031x

[7] E. Wickert, J. Marcondes, M. V. Lemos and E. G. M. Lemos, "Nitrogen Assimilation in Citrus Based on CitEST Data Mining,” Genetics and Molecular Biology, Vol. 30, No. 3, 2007, pp. 810-818. doi:10.1590/S1415-47572007000500009

[8] T. Das, "Rices in Bangladesh," Sadin Graphics, Mymensingh, 2005, p. 51.

[9] G. R. Steward and T. O. Orebamjo, "Some Unusal Characteristics of Nitrate Reduction in Erythrana senegalensis, DC,” New Phytologists, Vol. 83, No. 2, 1979, pp. 311319. doi:10.1111/j.1469-8137.1979.tb07456.x

[10] O. H. Lowery, N. J. Roserrough, A. L. Farr and R. J. Randall, "Protein Measurement with the Folienphenol Reagent,” Journal of Biological Chemistry, Vol. 183, No. 1, 1951, pp. 267-275.

[11] M. Dubois, A. K. Gilles, J. K. Hamilton, P. A. Robers, F. Smith, "Colorometric Method for Determination of Sugar and Related Substances," Analytical Chemistry, Vol. 28, No. 3, 1956, pp. 350-356. doi:10.1021/ac60111a017

[12] F. P. Gardner, R. B. Pearce and R. I. Mistechell, "Physiology of Crop Plants,” Iowa State University Press, Powa, 1985, p. 66.

[13] AOAC (Association of Official Analytical Chemistry), "Official Methods of Analysis," 13th Edition, Official Analytical Chemistry, Washington DC, 2004, pp. 127- 
129.

[14] D. F. Russel, "MSTAT-C Package Programme,” Crop and Soil Science Department, Michigan State University, East Lansing, 1986.

[15] K. A. Gomez and A. A. Gomez, "Statistical Procedures for Agriculture Research,” 2nd Edition, John Wiley and Sons, New York, 1984, p. 640.

[16] E. H. Murchie, J. C. Yang, S. Hubbart, P. Horton and S. B. Peng, "Are There Associations between Grain Filling Rate and Photosynthesis in the Flag Leaves of Field Grown Rice?” Journal of Experimental Botany, Vol. 53, No. 378, 2002, pp. 2217-2224. doi:10.1093/jxb/erf064

[17] N. M. Crawford, "Nitrate Nutrient and Signal for Plant Growth,” Plant Cell, Vol. 7, No. 7, 1995, pp. 859-868.

[18] M. K. Adak and D. K. D. Gupta, "Metabolic Activities in Some Rice Varieties under Submergence Stress," Indian Journal of Plant Physiology, Vol. 6, No. 3, 2001, pp. 1312-1316.

[19] M. M. Ali, A. Nurul, M. G. Hussain, F. K. N. Chowdhury, M. A. Ahsan and M. A. Jalil, "Nutritional Aspects of Rice Bran. Part 1. Amino Acid Content of Rice Bran,” Bangladesh Journal of Scientific and Industrial Research, Vol. 35, No. 1, 2000, pp. 1-4.

[20] J. Yamagishi, K. Nemoto and C. S. Mu, "Diversity of the Rachis Branching System in a Panicle in Japonica Rice," Plant Production Sciences, Vol. 6, No. 1, 2003, pp. 5964. doi:10.1626/pps.6.59

[21] G. Fu, L. Cf., L. Ml. L. and Z. Js, "Studies on Physiological Basis of High Yield of Indica Japonica Hybrid Rice Yayou 2,” Jiangsu Journal of Agricultural Sciences, Vol. 7, No. 1, 1991, pp. 15-19.

[22] A. Kusutani, M Toyata, K. Asanuma and J. Cui, "Studies on the Varietal Differences of Harvest Index and Mor- phological Characteristics of Rice," Japanese Journal of Crop Sciences, Vol. 69, No. 3, 2000, pp. 359-364. doi:10.1626/jcs.69.359

[23] K Fujita, V. P. Coronel and S. Yoshida, "Grain Filling Characteristics of Rice Varieties (Oryza sativa L.) Differing in Grain Size under Controlled Environmental Conditions," Soil Science and Plant Nutrition, Vol. 30, No. 3, 1984, pp. 445-454. doi:10.1080/00380768.1984.10434709

[24] P. B. Kadu, V. S. Bhoyar and S. K. Thankare, "Effect of NPK+FYM Blended Manurial Mixture on Performance of Rice,” Journal of Soils and Crops, Vol. 1, No. 2. 1991, pp. 172-174.

[25] T. Mae and K Ohira, "The Remobilization of Nitrogen Related to Leaf Growth and Senescence in Rice Plants (Oryza sativa L.),” Plant Cell Physiology, Vol. 22, 1981, pp. 1067-1074.

[26] K. Morita, "Release of Nitrogen from Chloroplast during Leaf Senescence in Rice (Oryza sativa L.)," Annals of Botany, Vol. 46, No. 3, 1980, pp. 297-302.

[27] T. Mae, A. Makino and K Ohira, "Ribulose-1, 5 Bisphosphate Carboxylase Synthesized and Degrade during Life Span of Rice Leaf (Oryza sativa L.)," Plant Cell Physiology, Vol. 24, No. 6, 1983, pp. 1079-1086.

[28] R.-X. Mo, L.-G. Jiang, L. Guo, J.-M. Hu, K.-Q. Liu, J.-M. Zhou, T.-F. Liang, K. Zeng and C.-Q. Ding, "Effects of Nitrogen Fertilizer Management on Nitrogen Contents in Different Forms in Rice Plants," Chinese Journal of Rice Sciences, Vol. 24, No. 1, 2010, pp. 49-54.

[29] X. Li, Z. W. Sun, L. Jin, L. Han, C. G. Ren, M. Wang and C. G. Li, "High/Low Nitrogen Adapted Hybrid of Rice Cultivars and Their Physiological Responses," African Journal of Biotechnology, Vol. 10, No. 19, 2011, pp. 37313738. 